\title{
Comparative Estimation of Exposure Level and Health Risk Assessment of Highly Produced Pesticides to Agriculture Operators by Using Default Dermal Absorption Rate or Actual Measurement Values
}

\author{
Su-Hyeon Kim ${ }^{1}$, Chang-Hun Lee ${ }^{1}$, Ki-Hun Kim ${ }^{1}$ and Sang-Hee Jeong ${ }^{1,2, \uparrow}$ \\ ${ }^{1}$ Department of Biomedical Science Research Institute, Hoseo University, Asan 31499, Korea \\ ${ }^{2}$ Department Biomedical Laboratory Science, Hoseo University, Asan 31499, Korea
}

Pesticides are widely used to prevent loss of agricultural production but extensive exposure can induce health problems to pesticide operators. This study was performed to evaluate the health risk of highly produced pesticides used in fruit growing farm land by comparison of estimated exposure level with AOEL using KO-POEM program. AOEL was driven based on NOAEL of each pesticide evaluated by JMPR, EFSA or KRDA. In calculation of exposure level, types of formulation, dilution factors, spraying duration and motor type and exposure protection device were allocated according to actual condition of use. Dermal absorption rate was differently applied among EFSA default values $(25 \%$ or $75 \%)$, general default value $(10 \%)$ or real test result values to know the plausibility of default values and safety of pesticide to operators in outline. Twenty pesticide ingredients (fungicides and insecticides) were produced more than 30 tons per year, which were mancozeb, chlorothalonil, imidaclopirid and etc in order. Dermal absorption rates obtained from studies were various from 0.07 to $81 \%$ but mostly under $10 \%$. The estimated exposure levels showed big differences more than 10 times higher when using EFSA default rate and up to 5 times higher when using general rate of $10 \%$ comparing using rates of test results. Mancozeb, chlorthalonil, diazinon and chlorpyrifos presented still higher exposure level than AOEL even when using test absorption rate from study, which suggests that re-evaluation of AOEL or dermal exposure absorption rate or strict management are required for health protection of operators who use those four pesticides in farm land.

Key Words: Pesticide operator, Risk assessment, AOEL, Dermal absorption rate, Estimated exposure level

\section{INTRODUCTION}

Pesticides are widely used to control harmful insects and to prevent loss of agricultural production. However, high exposure can induce health problems including neurotoxicity, hepatotoxicity and etc. to pesticide operators (Choi and Kim, 2014). Therefore, Acceptable Operator Exposure Level (AOEL) is established during authorization of pesticides to prevent the exposure level does not exceed operators' health protection level, AOEL (You et al., 2014).

Field workers get a majority of internal dose through dermal contact to pesticides and most pesticides have low to moderate vapor pressure. It was reported that more than $90 \%$ of total exposure is come from the skin contact during application of agrochemicals (Finley et al., 1994; kim et al., 2012). In calculation of exposure level of pesticide to operators, dermal absorption rate, dilution factor, kind of solvent,

\footnotetext{
* Received: November 18, 2016 / Accepted: January 1, 2017

${ }^{\dagger}$ Corresponding author: Sang-Hee Jeong. Department of Biomedical Laboratory Science, Hoseo University, Asan 31499, Korea.

Tel: +82-41-540-9675, Fax: +82-41-540-9829, e-mail: jeongsh@hoseo.edu

(C) The Korean Society for Biomedical Laboratory Sciences. All rights reserved.

(c) This is an Open Access article distributed under the terms of the Creative Commons Attribution Non-Commercial License (http://creativecommons.org/licenses/by-nc/3.0/) which permits unrestricted non-commercial use, distribution, and reproduction in any medium, provided the original work is properly cited.
} 
spraying duration, spraying motor type and exposure protection device are all key factors for precise estimation (Ueda et al., 2009). Among them, dermal absorption rate is the most important factor for calculation of internal dose of pesticide because internal dose is dependent on penetration efficacy through skin barrier (Poet, 2000).

UK-POEM or KO-POEM were kinds of developed models to measure exposure level of pesticide to operators. When measuring exposure level of pesticide to operator by using the models, dermal absorption rate should be presented for each pesticide product. However, information of dermal absorption rate was limited. EFSA recommended default dermal absorption rate $75 \%$ when the concentration of active ingredient in a product is lower than $5 \%$ and $25 \%$ when active ingredient is higher than 5\% (EFSA, 2012). Also, default dermal absorption rate $10 \%$ was also suggested by EFSA (2012) for chemicals with a molecular weight higher than 500 and $\log$ Kow value smaller than -1 or higher than 4 .

This study was performed to evaluate the health risk of highly produced pesticides used in fruit growing farmland by comparison of estimated exposure level with AOEL. The exposure level was driven by using three kinds of different dermal absorption rates, which were EFSA default values $(25 \%$ or $75 \%)$, general default value $(10 \%)$ or actual measurement values coming from study to know the safety of pesticide to operators' health and the plausibility of default dermal absorption rates in estimation of exposure level.

\section{MATERIALS AND METHODS}

\section{Selection of pesticides and information survey}

To select highly produced pesticides (more than 30 tons/ year), information of annual production amount of pesticide and methods of pesticides using in field were obtained through the annual report of pesticide crop protection guideline (Korea Crop Protection Association, 2015).

\section{AOEL evaluations}

Information of point of departure values of toxicity (NOAEL) and AOEL were obtained through JMPR, EFSA and Korea RDA.

\section{Estimation of exposure level}

KO-POEM program was used to drive pesticide exposure level to operators. Parameters including working time, work rate, method of spraying and personal protection device used for the calculation of exposure amount of pesticide to operators were presented in Table 3. The exposure level of highly produced pesticides to operators were calculated by using EFSA default dermal absorption rate values $(25 \%$ or $75 \%$ ), typically used default values (10\%) and actual absorption rate obtained from studies. Related to this scheme of application of dermal absorption rate was shown in Fig. 1.

\section{Risk assessment for pesticide operators}

For pesticide operator health risk assessment, the ratio of estimated exposure level driven from KO-POEM per AOEL (Toxic Exposure Ratio, TER) was calculated. Risk assess-

Table 1. Highly produced pesticides (more than 30 tons/year) in 2015 in KOREA

\begin{tabular}{lcl}
\hline \hline Ingredient & $\begin{array}{c}\text { Annual Output } \\
\text { (tons/year) }\end{array}$ & Category \\
\hline Mancozeb & 1,640 & Fungicide \\
Chlorothalonil & 443 & Fungicide \\
Imidacloprid & 355 & Insecticide \\
Propineb & 243 & Fungicide \\
Thiophanate-methyl & 208 & Fungicide \\
Dithianon & 93 & Fungicide \\
Myclobutanil & 64 & Fungicide \\
Diazinon & 63 & Insecticide \\
Acibenzolar-S-methyl & 55 & Fungicide \\
Acephate & 52 & Insecticide \\
Iprodione & 49 & Fungicide \\
Fluazinam & 49 & Fungicide \\
Metalaxyl & 49 & Fungicide \\
Captan & 47 & Fungicide \\
Copper oxychloride & 44 & Fungicide \\
Kasugamycin & 44 & Fungicide \\
Cypermethrin & 43 & Insecticide \\
Copper hydroxide & 38 & Fungicide \\
Chlorpyrifos & 34 & Insecticide \\
Tebuconazole & 34 & Fungicide \\
\hline
\end{tabular}


ment for pesticide operator was based on TER. It was judged to be hazard if TER exceed 1 and to be safe when TER equal to or below 1 .

\section{RESULTS}

\section{Highly produced pesticides and their use in farmland}

20 pesticides were produced more than 30 tons per year in 2015 in KOREA among fungicides and insecticides used in fruit growing farmland (Korea Crop Protection Association 2015) Mancozeb (1,640 tons), chlorothalonil (443 tons), imidacloprid (355 tones), propineb (243 tons) and thiopanatemethyl (208 tons) and etc were found highly produced pesticides in order (Table 1).

\section{AOEL of highly produced pesticides}

Point of departure values of toxicity (NOAEL) and AOEL were obtained through JMPR, EFSA and Korea RDA (Table 2). For 20 kinds of highly produced pesticides, AOELs were ranged from 0.0002 to $0.19 \mathrm{mg} / \mathrm{kg}$ bw/day. The endpoint toxicities were found in mainly 90 days repeat oral toxicity studies in rats or dogs and toxicities including thyroid gland

Table 2. Toxicity values (NOAEL), AOEL and dermal absorption rate of highly produced pesticides

\begin{tabular}{|c|c|c|c|}
\hline Ingredient & Toxicity (NOAEL, mg/kg bw/day) & $\begin{array}{c}\mathrm{AOEL} \\
\text { (mg/kg bw/ } \\
\text { day) }\end{array}$ & $\begin{array}{l}\text { Dermal absorption rate } \\
\text { from actual test }\end{array}$ \\
\hline Mancozeb & $\begin{array}{l}\text { Rat 90days repeat/oral: Inhibition of thyroid peroxidase, thyroid } \\
\text { hyperplasia ( } 7 \text { ) }\end{array}$ & $0.035^{\mathrm{a})}$ & $\mathrm{C}: 1 \%, \mathrm{D}: 4 \%{ }^{\mathrm{d})}$ \\
\hline Chlorothalonil & $\begin{array}{l}\text { Rat 1year repeat/oral: Tumor pre-symptom in kidney and } \\
\text { stomach }(2.7)\end{array}$ & $0.009^{\mathrm{a})}$ & $\mathrm{D}: 10 \%{ }^{\mathrm{e})}$ \\
\hline Imidacloprid & $\begin{array}{l}\text { Rabbit teratology toxicity: Decrease of maternal body weight } \\
\text { and feed intake ( } 8 \text { ) }\end{array}$ & $0.08^{\text {a) }}$ & $\left.\mathrm{C}: 7.9 \%, \mathrm{D}: 11.4 \%{ }^{\mathrm{f}}\right)$ \\
\hline Propineb & Rat 90days repeat/oral: Muscle atrophy (7.6) & $0.046^{\mathrm{a})}$ & - \\
\hline Thiophanate-methyl & Dog 1year repeat/oral: Increased liver weight, anemia (8) & $0.08^{\text {a) }}$ & - \\
\hline Dithianon & Dog 90days repeat/oral: Liver, kidney toxicity (3) & $0.014^{\mathrm{a})}$ & $\mathrm{C}: 0.07 \%, \mathrm{D}: 0.79 \% \mathrm{o}^{\mathrm{g})}$ \\
\hline Myclobutanil & Dog lyear repeat/oral: Increased liver weight, hepatomegaly (3.09) & $0.031^{\text {a) }}$ & $\mathrm{D}: 25 \%^{\mathrm{h})}$ \\
\hline Diazinon & Dog 90days repeat/oral: Cholinesterase inhibition (0.02) & $0.0002^{\mathrm{a})}$ & $\mathrm{D}: 14.1 \%$ i) \\
\hline Acibenzolar-S-methyl & Dog 90day sub-acute toxicity: Haemolytic anaemia (10) & $0.03^{\mathrm{b})}$ & $\left.C: 16 \%, D: 81 \%{ }^{j}\right)$ \\
\hline Acephate & Rat 90days repeat/oral: Cholinesterase inhibition ( 0.58$)$ & $0.0058^{\mathrm{a})}$ & - \\
\hline Iprodione & $\begin{array}{l}\text { Rat 90days repeat/oral: Changed weight of liver and adrenal gland } \\
\text { (31) }\end{array}$ & $0.19^{\text {a) }}$ & $\mathrm{D}: 0.65 \%{ }^{\mathrm{k})}$ \\
\hline Fluazinam & Rabbit teratology toxicity: Delayed ossification (1) & $0.0035^{\mathrm{a})}$ & - \\
\hline Metalaxyl & Dog 90days repeat/oral: Liver toxicity, anemia (8) & $0.08^{\text {a) }}$ & - \\
\hline Captan & Rabbit teratology study: Teratogenesis of fetus (10) & $0.1^{\mathrm{c})}$ & $\mathrm{D}: 0.9 \%$ \\
\hline Copper oxychloride & Human: Non toxic $(0.2)$ & $0.072^{\mathrm{a})}$ & - \\
\hline Kasugamycin & Rabbit teratology study: Decreased weight, abortion (10) & $0.01^{\text {a) }}$ & - \\
\hline Cypermethrin & Dog 90days repeat/oral: Disordered nervous system (12.5) & $0.063^{\mathrm{a})}$ & $\left.\mathrm{D}: 25 \%{ }^{\mathrm{m}}\right)$ \\
\hline Copper hydroxide & Human: Non toxic $(0.2)$ & $0.072^{\mathrm{a})}$ & - \\
\hline Chlorpyrifos & $\begin{array}{l}\text { Rat comparative cholinesterase assay repeat/oral: } \\
\text { Cholinesterase inhibition }(0.1)\end{array}$ & $0.001^{\text {a) }}$ & $\mathrm{D}: 1 \%{ }^{\mathrm{n})}$ \\
\hline Tebuconazole & Dog 1year repeat/oral: Adrenal zona fasciculata cell hypertrophy (3) & $0.03^{\text {a) }}$ & - \\
\hline
\end{tabular}

C: Original product formulation, D: Diluted product for spraying, -: No data provided

a) National Institute of Agricultural Science KOREA (2016), ${ }^{\text {b) }}$ European Commission (2002), ${ }^{\text {c) }}$ European Commission (2008), ${ }^{\text {d) }}$ INCHEM,

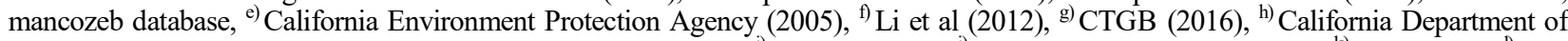
Food and Agriculture Worker Health and Safety Branch (1988), ${ }^{i}$ NPIC database, ${ }^{\text {j) }}$ European Commission (2002), ${ }^{\text {k) }}$ EPA (1995), ${ }^{1)}$ EPA (1997), ${ }^{\text {m) }}$ EPA (1996), ${ }^{\text {n) }}$ European Commission (2005) 
Table 3. Condition of pesticide use including working time, work rate and method of spraying for the calculation of exposure level of pesticide to operators

\begin{tabular}{|c|c|c|c|c|}
\hline \multirow{3}{*}{ Pesticide formulation } & \multicolumn{2}{|c|}{ Wearable device for protection } & \multirow{2}{*}{$\begin{array}{l}1 \text { day spraying area } \\
\text { (Work rate/day) }\end{array}$} & \multirow{3}{*}{$\begin{array}{l}1 \text { day } \\
\text { spraying time }\end{array}$} \\
\hline & During mix/loading & Spraying application & & \\
\hline & Speed sprayer & Speed sprayer & Speed sprayer & \\
\hline Water dispersible granule & Glove and mask (FFP3) & Glove & 2 ha & $6 \mathrm{hr}$ \\
\hline Wattable powder & Glove and mask (FFP3) & Glove & 2 ha & $6 \mathrm{hr}$ \\
\hline Emulsifiable concentrate & Glove & Glove & 2 ha & $6 \mathrm{hr}$ \\
\hline Liquid Formulation & Glove & Glove & 2 ha & $6 \mathrm{hr}$ \\
\hline
\end{tabular}

hyperplasia in rats, increased liver weight in dogs, cholinesterase inhibition in rats, delayed ossification in rabbits and etc (Table 2). The lowest AOEL among those of 20 pesticides was $0.0002 \mathrm{mg} / \mathrm{kg}$ bw/day for diazinon and the endpoint toxicity was cholinesterase inhibition in dogs treated orally for 90 days with NOAEL $0.02 \mathrm{mg} / \mathrm{kg}$ bw/day.

In case for propineb, thiopanate-methyl, acepate, fluazinam, metalaxyl, copper oxychloride, kasugamycin, copper hydroxide and tebuconazol, there were no information of dermal absorption rate. Other pesticides have information of dermal absorption rate for concentrated formula or diluted solution used for spraying. The absorption rate was from $0.07 \%$ to $81 \%$ (Table 2). When dermal absorption rates were provided both for concentrated and diluted products such as mancozeb, imidacloprid, dithianon and acibenzolar-S-methyl, that of diluted solution was higher than concentrated formula of same product ranged from 1.4 to 10 times.

\section{Estimation of exposure level}

In calculation of the exposure level using the KO-POEM program, pesticide formulation type, protective equipment, application method, work rate/day, dose, application volume, duration of spraying was inputted according to the actual condition of use as presented in Table 3.

The estimated exposure level calculated were the highest when using EFSA default dermal absorption values $(25 \%$ or $75 \%$ ) and the lowest when using actual measurement values and the differences were mostly 10 times higher in case using EFSA default values. This means the EFSA approach of using default dermal absorption rate is too conservative in estimation of operator exposure level of pesticides.

The estimated exposure level was similar or a little higher when using $10 \%$ default values comparing when using actual measurement values. This results showed that $10 \%$ default dermal absorption rate used by KRDA may be appropriate for exposure assessment of pesticide products with limited information. Aggarwal et al. (2015) presented that $6 \%$ for liquid and $2 \%$ for solid concentrates, irrespective of active substance loading, were appropriate as for default values of dermal absorption rate when no information was available.

\section{Risk assessment for pesticide operators}

When using estimated exposure level derived from EFSA default dermal absorption rate, 35 kinds of products among 41 products showed TER higher than 1. Diazinon wettable powder had TER 1350. Still 24 pesticide products have TER higher than 1 when using default dermal absorption rate $10 \%$. Among 22 pesticide products which have actual measurement values of dermal adsorption rates from in vitro or in vivo studies, 9 products showed TER higher than 1, which products are mancozeb (WP), chlorthalonil (WP, FL, WG), some products of dithianon (WP), diazinon (WP) and chlorpyrifos (WP, FL, EC) (Table 4).

Among pesticide products which information of dermal absorption rate were not available, propioneb (WP), acepate (WP), fluazinam (WP, FL, WG), several products of copper oxychloride (WP) and kasugamycin (FL, WG), copper hydroxide (WP) and tebuconazole (WP, EC) presented TER higher than 1 when using estimated exposure level of default dermal absorption rate $10 \%$. 
Table 4. Ratio of estimated exposure level/AOEL of pesticides which dermal absorption rate coming from EFSA default values, general default values and actual measurement values from study under speed sprayer condition

\begin{tabular}{|c|c|c|c|c|c|}
\hline \multirow[b]{2}{*}{ Ingredient } & \multirow{2}{*}{$\begin{array}{c}\text { AOEL } \\
(\mathrm{mg} / \mathrm{kg} \mathrm{bw} / \\
\text { day) }\end{array}$} & \multirow[b]{2}{*}{ Formula } & \multicolumn{3}{|c|}{ Estimated Exposure level $\left(\mathrm{TER}^{\mathrm{a}}\right)$} \\
\hline & & & EFSA default rates & General default rates & $\begin{array}{c}\text { Actual measurement } \\
\text { values }\end{array}$ \\
\hline Mancozeb & 0.035 & WP & $0.60 \sim 1.62(17.28 \sim 46.29)$ & $0.07 \sim 0.23(2.1 \sim 6.6)$ & $0.03 \sim 0.10(0.92 \sim 2.87)$ \\
\hline Chlorothalonil & 0.009 & $\begin{array}{l}\text { WP } \\
\text { FL } \\
\text { WG }\end{array}$ & $\begin{array}{l}0.29 \sim 1.62(32.40 \sim 180.01) \\
0.22 \sim 0.57(24.00 \sim 63.60) \\
0.57(63.88)\end{array}$ & $\begin{array}{l}0.04 \sim 0.23(4.62 \sim 25.66) \\
0.03 \sim 0.08(3.42 \sim 9.07) \\
0.08(8.90)\end{array}$ & $\begin{array}{l}0.03 \sim 0.24(3.49 \sim 26.17) \\
0.03 \sim 0.08(3.49 \sim 9.25) \\
0.08(8.98)\end{array}$ \\
\hline Imidacloprid & 0.08 & $\begin{array}{l}\text { WP } \\
\text { WG } \\
\text { FL } \\
\text { LF }\end{array}$ & $\begin{array}{l}0.02 \sim 0.05(0.22 \sim 0.68) \\
0.05(0.65) \\
0.03 \sim 0.05(0.03 \sim 0.61) \\
0.01(0.08)\end{array}$ & $\begin{array}{l}0.00 \sim 0.01(0.05 \sim 0.10) \\
0.01(0.09) \\
0.00 \sim 0.01(0.05 \sim 0.09) \\
0.05(0.59)\end{array}$ & $\begin{array}{l}0.00 \sim 0.01(0.05 \sim 0.11) \\
0.01(0.10) \\
0.01(0.09) \\
0.01(0.09)\end{array}$ \\
\hline Propineb & 0.046 & WP & $1.51(32.87)$ & $0.22(4.69)$ & - \\
\hline Thiophanate-methyl & 0.08 & $\begin{array}{l}\text { WP } \\
\text { FL }\end{array}$ & $\begin{array}{l}0.08 \sim 0.76(0.95 \sim 9.45) \\
0.22 \sim 0.54(2.70 \sim 6.71)\end{array}$ & $\begin{array}{l}0.01 \sim 0.11(0.13 \sim 1.35) \\
0.03 \sim 0.07(0.39 \sim 0.94)\end{array}$ & - \\
\hline Dithianon & 0.014 & $\begin{array}{l}\text { WP } \\
\text { FL } \\
\text { WG }\end{array}$ & $\begin{array}{l}0.14 \sim 0.81(10.03 \sim 57.86) \\
0.22 \sim 0.46(15.43 \sim 23.14) \\
0.32 \sim 0.71(3.21 \sim 7.06)\end{array}$ & $\begin{array}{l}0.02 \sim 0.12(1.43 \sim 8.25) \\
0.03 \sim 0.07(2.20 \sim 4.73) \\
0.04 \sim 0.10(23.01 \sim 50.63)\end{array}$ & $\begin{array}{l}0.00 \sim 0.02(0.20 \sim 1.13) \\
0.00 \sim 0.01(0.30 \sim 0.65) \\
0.01(0.39 \sim 0.85)\end{array}$ \\
\hline Myclobutanil & 0.031 & WP & $0.04 \sim 0.06(1.45 \sim 2.16)$ & $0.01(0.21 \sim 0.37)$ & $0.02(0.51 \sim 0.74)$ \\
\hline Diazinon & 0.0002 & WP & $0.27(1350.05)$ & $0.04(192.48)$ & $0.05(269.08)$ \\
\hline Acibenzolar-S-methyl & 0.03 & $\begin{array}{l}\text { WP } \\
\text { FL }\end{array}$ & $\begin{array}{l}0.01(0.36) \\
0.02(0.51 \sim 0.64)\end{array}$ & $\begin{array}{l}0.00(0.05) \\
0.00(0.07 \sim 0.09)\end{array}$ & $\begin{array}{l}0.01(0.39) \\
0.02(0.54 \sim 0.68)\end{array}$ \\
\hline Acephate & 0.0058 & WP & $0.22(37.24)$ & $0.03(5.31)$ & - \\
\hline Iprodione & 0.19 & $\begin{array}{l}\text { WP } \\
\text { FL }\end{array}$ & $\begin{array}{l}0.27 \sim 0.54(0.20 \sim 0.41) \\
0.46(2.44)\end{array}$ & $\begin{array}{l}0.04 \sim 0.08(1.42 \sim 2.84) \\
0.07(0.35)\end{array}$ & $\begin{array}{l}0.01(0.03 \sim 0.04) \\
0.01(0.05)\end{array}$ \\
\hline Fluazinam & 0.0035 & $\begin{array}{l}\text { WP } \\
\text { FL } \\
\text { WG }\end{array}$ & $\begin{array}{l}0.17 \sim 0.27(49.37 \sim 77.15) \\
0.16 \sim 0.27(44.74 \sim 77.15) \\
0.27(76.71)\end{array}$ & $\begin{array}{l}0.02 \sim 0.04(7.04 \sim 11.00) \\
0.02 \sim 0.04(6.38 \sim 11.00) \\
0.04(10.69)\end{array}$ & - \\
\hline Metalaxyl & 0.08 & WP & $0.16(2.03)$ & $0.02(0.29)$ & - \\
\hline Captan & 0.1 & $\begin{array}{l}\text { WP } \\
\text { WG }\end{array}$ & $\begin{array}{l}1.08 \sim 1.30(10.80 \sim 12.96) \\
0.54(5.37)\end{array}$ & $\begin{array}{l}0.15 \sim 0.18(1.54 \sim 1.85) \\
0.07(0.75)\end{array}$ & $\begin{array}{l}0.03(0.28 \sim 0.33) \\
0.01(0.11)\end{array}$ \\
\hline Copper oxychloride & 0.072 & WP & $0.25 \sim 0.91(3.47 \sim 12.60)$ & $0.04 \sim 0.13(0.49 \sim 1.80)$ & - \\
\hline Kasugamycin & 0.01 & $\begin{array}{l}\text { WP } \\
\text { FL } \\
\text { WG }\end{array}$ & $\begin{array}{l}0.04 \sim 0.06(3.73 \sim 6.21) \\
0.08 \sim 0.11(4.36 \sim 8.05) \\
0.04 \sim 0.05(10.74)\end{array}$ & $\begin{array}{l}0.01(0.53 \sim 0.89) \\
0.01(0.62 \sim 1.12) \\
0.01(1.50)\end{array}$ & - \\
\hline Cypermethrin & 0.063 & $\mathrm{EC}$ & $0.06(0.91)$ & $0.01(0.14)$ & $0.02(0.35)$ \\
\hline Copper hydroxide & 0.072 & $\begin{array}{l}\text { WP } \\
\text { WG }\end{array}$ & $\begin{array}{l}0.54 \sim 0.83(7.50 \sim 11.55) \\
0.50(6.92)\end{array}$ & $\begin{array}{l}0.08 \sim 0.12(1.07 \sim 1.65) \\
0.07(0.96)\end{array}$ & - \\
\hline Chlorpyrifos & 0.001 & $\begin{array}{l}\text { WP } \\
\text { FL } \\
\text { EC }\end{array}$ & $\begin{array}{l}0.16 \sim 0.34(162.01 \sim 337.51) \\
0.16(162.01) \\
0.11 \sim 0.47(114.50 \sim 465.15)\end{array}$ & $\begin{array}{l}0.02 \sim 0.05(23.10 \sim 48.12) \\
0.02(23.10) \\
0.02 \sim 0.07(28.80 \sim 68.04)\end{array}$ & $\begin{array}{l}0.00 \sim 0.01(4.39 \sim 9.14) \\
0.00 \sim 0.02(4.39 \sim 22.68) \\
0.01 \sim 0.02(9.42 \sim 22.68)\end{array}$ \\
\hline Tebuconazole & 0.03 & $\begin{array}{l}\text { WP } \\
\text { EC } \\
\text { FL } \\
\text { WG }\end{array}$ & $\begin{array}{l}0.08 \sim 0.25(2.70 \sim 8.28) \\
0.15 \sim 0.20(5.08 \sim 6.57) \\
0.04 \sim 0.18(1.44 \sim 6.00) \\
0.13(4.47)\end{array}$ & $\begin{array}{l}0.01 \sim 0.04(0.38 \sim 1.18) \\
0.03(0.86 \sim 1.07) \\
0.01 \sim 0.03(0.21 \sim 0.86) \\
0.02(0.62)\end{array}$ & - \\
\hline
\end{tabular}

WP: Wettable powder, FL: Flowable, WG: Water-dispersible granule, LF: Liquid formulation, EC: Emulsifiable concentrate, -: No data provided a) TER (Toxic exposure ratio) = Estimated exposure level/AOEL, estimated exposure level was driven by application of EFSA default dermal absorption rate $(25 \%$ or $75 \%)$ or general default rate $(10 \%)$ or actual dermal absorption rate coming from in vitro or in vivo study

Actual measurement value of dermal absorption rate is very important for estimation of accurate exposure level.
This study showed the exposure level is directly dependent on dermal absorption rate and EFSA approach using default 
dermal absorption rate $25 \%$ or $75 \%$ is too conservative and does not reflect actual situation comparing general dermal absorption rate $10 \%$.

\section{DISCUSSION}

Pesticides are widely used to prevent the loss of agricultural production, but they can cause health problems to pesticide operators. Therefore, operator's health risk assessment of highly produced pesticides used in farm land is required.

Operator's health risk assessment is performed by the comparison of estimated exposure level with AOEL if TER is higher than 1, it is concerned level for operator's health.

In Korea, after reviewing all toxicological data such as acute toxicity, short-term toxicity, chronic toxicity, carcinogenicity, reproductive toxicity, teratogenicity and genotoxicity, AOEL is decided. In many cases, AOEL was set based on NOAEL of 90 days or short-term toxicity and by considering uncertainties of interspecies and individual differences and data gaps of studies (Damalas and Eleftherohorinos, 2011; Hong et al., 2007, 2010; You et al., 2014). In addition, the oral absorption rate was used as a correction factor to convert the external dose to the internal dose when oral absorption rate was less than $80 \%$ (You et al., 2014).

Dermal absorption rate is one of key factors for estimation of exposure level of pesticides to operators (Ueda et al., 2009). Exposure level of highly produced pesticides to operators was calculated by using EFSA default dermal absorption rate values $(10 \%, 25 \%$ or $75 \%)$, typical default

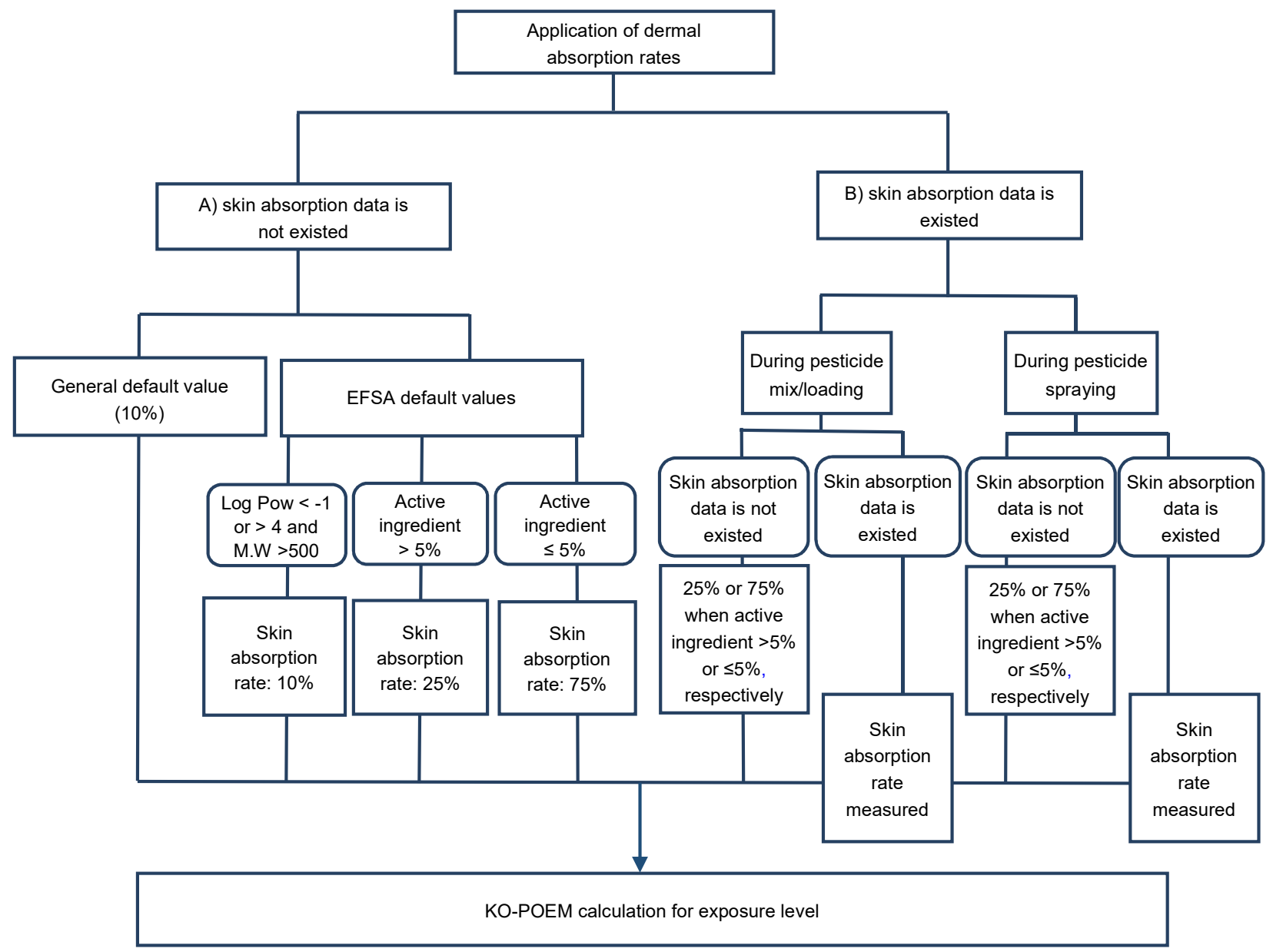

Fig. 1. Scheme of application of dermal absorption rate for estimation of exposure level. 
value $(10 \%)$ or actual measurement rate obtained from studies and then compared the estimated levels with each other. $25 \%$ dermal absorption rate was allocated when active substance content is higher than 5\% and 75\% dermal absorption rate was used when active substance content is equal to or lower than $5 \%$ according to EFSA recommendation. Default $10 \%$ dermal absorption rate was also used because it is accepted and used by KRDA but EFSA accept the value when a chemical having $\log$ Pow $<-4$ or $>1$ and molecular weight $>500$. Related to this scheme of application of dermal absorption rate was shown in Fig. 1.

Aggarwal et al. (2015) reported that absorption does not increase linearly beyond a 5-fold increase in dilution comparing concentrated one and as for default dermal absorption rate $30 \%$ was proposed for all spray dilution. In our investigation the dermal absorption rate of diluted spray was lower than $30 \%$ except acibenzolar-S-methyl. EU recommends default absorption rate $75 \%$ when the concentration of ingredient is lower than $5 \%$, which value was found too conservative considering actual measurement values.

Actual measurement value of dermal absorption rate is very important for estimation of accurate exposure level. The estimated exposure level was similar or a little higher when using $10 \%$ default values comparing when using actual measurement values. This results showed that $10 \%$ default dermal absorption rate used by KRDA may be appropriate for exposure assessment of pesticide products with limited information.

The degree of pesticide hazard by dermal absorption is related with the toxicity potency of pesticide, duration of the exposure, pesticide formulation, spraying types and the absorption rate (Dosemeci et al., 2001).

In our study diazinon presented too high exposure level comparing AOEL of $0.0002 \mathrm{mg} / \mathrm{kg}$ bw/day. Chlorthalonil and chlorpyrifos also showed risk concern for operators when they use any kinds of formula of the pesticides even when estimate exposure level using actual measurement values. And also propineb, acepate and fluazinam need information of actual dermal absorption rate by study for higher TER by using 10\% default dermal absorption rate.

In conclusion, this study presented outlined health risk of highly produced pesticides used in fruit growing farmland when operators are exposed to the pesticides during loading and spraying and proposed that re-evaluation or study of dermal absorption rate are required for diazinon, chlorthalonil, chlorpyrifos, propineb, acepate and fluzinam because the estimated exposure levels are calculated higher than AOEL and the amount of use are high in agriculture area.

\section{Abbreviations}

AOEL: Acceptable Operator Exposure Level; KO-POEM: Korea Predictive Operator Exposure Model; NOAEL: NOObserved-Adverse-Effect-Level; JMPR: FAO/WHO Joint Meeting of Pesticide Residue; EFSA: European Food Safety Agency; KRDA: Korea Rural Development Administration

\section{Acknowledgements}

This work was carried out with the support of "Cooperative Research Program for Agriculture Science and Technology Development (Project title: Systemic Toxicological Research of Pesticide Exposure to Agricultural Workers, Project No. PJ0099502016)" Rural Development Administration, Republic of Korea.

\section{Conflict of interest}

The authors declare that they have no competing interests.

\section{REFERENCES}

Aggarwal M, Fisher P, Huser A, Kluxen FM, Parr-Dobrzanski, Soufi M, Strupp C, Wiemann C, Billington R. Assessment of an extended dataset of in vitro human dermal absorption studies on pesticides to determine default values, opportunities for read-across and influence of dilution on absorption. Regul Toxicol Pharmacol. 2015. 72: 58-70.

California Environment Protection Agency. Chlorothalonil risk chracterization document for dietary exposure. 2005.

California Department of Food and Agriculture Worker Health and Safety Branch. Human Exposure Assessment Myclobutanil. 1988.

Choi H, Kim JH. Risk assessment of agricultural worker's exposure to fungicide thiophanate-methyl during treatment in green pepper, cucumber and apple fields. KSABC. 2014. 57: 73-81.

CTGB Netherlands. Registration report part A risk management 
dithianon. 2016.

Damalas CA, Eleftherohorinos. Pesticide exposure, safety issues, and risk assessment indicators. IJERPH. 2011. 8: 1402-1419.

Dosemeci M, Alavanja MCR, Rowland AS, Mage D, Zahm SH, Rothman N, Lubin JH, Hoppin JA, Sangler DP, Blair A. A quantitative approach for estimating exposure to pesticides in the agricultural health study. Ann Occup Hyg. 2001. 46: 245 -260 .

EFSA. EFSA (European Food Safety Authority) Guidance on dermal absorption. 2012. 10: 2665.

EPA. Captan (N-trichlormathylthio-4-cyclohexane-1,2-dicarboximide): hazzard identification committee report. 1997.

EPA. Iprodione-mouse micronucleus test, mechanistic studies, and a dermal absorption study. 1995.

EPA. Occupational and residential exposure assessment and recommendations for the reregistration eligibility decision document for cypermethrin. 1996.

EU database: http://ec.europa.eu/food/plant/pesticides/eupesticidesdatabase/public/?event=homepage\&languag e $=\mathrm{EN}$

European Commission. Review report for the active substance acibenzolar-s-methyl. 2002.

European Commission. Review report for the active substance captan. 2008.

European Commission. Review report for the active substance chlorpyrifos. 2005

Finley BL, Scott PP, Harrington N, Paustenbach D, Price P. Recommended distributions for exposure factors frequently used in health risk assessment. Risk Anal. 1994. 14: 533-553.

Hong SS, Jeong MH, Park KH, You AS, Park YK, Lee JB, Kim CS, Shin JS, Park JE. The Preliminary operator risk assessment of highly toxicological pesticides in Korea. KJPS. 2010. 14: 116-122.

Hong SS, Lee JB, Park YK, Shin JS, Im GJ, Ryu GH. The proposal for pesticide exposure estimation of Korean orchard farmer. KJPS. 2007. 11: 281-288.

INCHEM mancozeb database: http://www.inchem.org/documents/ jmpr/jmpmono/v93pr1 1.htm

JMPR database: http://apps.who.int/pesticide-residues-jmpr-database

Kim EH, Lee HR, Jeong MH, Hong SS, Kim JH. Hand exposure of operator to chlorpyrifos during mix/loading and risk assess ment. KJPS. 2012. 16: 391-394.

Korea Crop Protection Association. Chronological list of pesticide. 2015.

Li CX, LI M, Feng XL, Cao P, Wang XD, Liu S, Xu HB. Study on dermal absorption of imidacloprid in vitro. CJIHOD. 2012. 30: 604-607.

National Institute of Agricultural Science KOREA. 19th pesticide safety committee report. 2016.

NPIC database: http://npic.orst.edu/factsheets/archive/diazinontech.html\#references

Poet TS. Assessing Dermal Absorption. Toxicol. Sci. 2000. 58: 1-2.

Ueda CT, Shah VP, Derdzinski K, Ewing G, Flynn G, Maibach H, Marques M, Rytting H, Shaw S, Thakker K, Yacobi A. Topical and transdermal drug products. Pharmacopeial Forum. 2009. 35: 470-764.

You AS, Hong SS, Lee JB, Lee SD, Ihm YB. Application of oral absorption in establishment of AOEL for pesticides and occupational risk assessment for farm worker. KJPS. 2014. 18: 342-349. 